\title{
Chapter 3 \\ Shifting Risk into Productivity: Inclusive and Regenerative Approaches Within Compromised Contexts in Peri-Urban Areas
}

Francesca Garzilli $(\mathbb{D}$, Federica Vingelli $(\mathbb{D}$, and Valentina Vittiglio $\mathbb{D}$

\subsection{Overlapping Risks in Peri-Urban Areas}

Due to the increase in the intensity and frequency of disasters in urban areas, especially related to climate change (IPCC, 2014), the issue of risk has increasingly been debated by academics, policymakers and the general public, along with the growing awareness of the role of people in protecting the planet and the territory.

This section introduces the concept of risk and the evolution of knowledge of its implications on the forms of landscape, affirming that an in-depth understanding of the territorial fragilities is one of the main challenges for designing a sustainable and regenerative development methodology, able to effectively address territorial vulnerabilities.

The issue of risk has strong territorial implications: it can "mark" the territory (positively or negatively) and it can be viewed as a projection into the future of territorial features that effectively endanger the space in question (November, 2004):

The section on "Overlapping risks in peri-urban areas" and "Territorial risks and resources in Campania" was written by Federica Vingelli, the section on "Land productivity: from exploitation toward regeneration" by Francesca Garzilli, the section on "Adaptive remediation approach for periurbanity in transition" by Valentina Vittiglio, the section on "The Agency of Waste" by Francesca Garzilli and Valentina Vittiglio, and the abstract and concluding remarks are the result of shared work.

F. Garzilli · F. Vingelli

Department of Architecture, University of Naples Federico II, Naples, Italy

e-mail: francesca.garzilli@unina.it

F. Vingelli

e-mail: federica.vingelli@unina.it

V. Vittiglio (凶)

Department of Architecture and Industrial Design, University of Campania Luigi Vanvitelli,

Aversa, Italy

e-mail: valentina.vittiglio@unicampania.it 
for example an earthquake or a volcano eruption, in the case of natural risks, or industrial accidents, contamination, in the case of human-made risk.

Significant progress has been made in the study of the relations between risk, society and territory since the 1970 s. Early conducted on risk were predominantly hazard-orientated, and disaster events were perceived as random, exceptional events or "acts of nature", as the expression "natural disaster" shows (Burton, 2005, p. 35). Then, in the late 1970s, the United Nations Disaster Relief Organization (UNDRO) globally recognized the social construction of risk (White, 1974). Their definition of risk included three components: hazard, risk and vulnerability. ${ }^{1}$ This definition recognizes that disasters are not sudden events, but they are results of the combination of multiple variables including the vulnerability of exposed elements or areas, and their physical, economic and environmental qualities (Peduzzi, 2019). Later, this change of perspective was largely adopted by scientific studies, and by the first Terminology on Disaster Risk Reduction that was published by the United Nations International Office for Disaster Risk Reduction (UNISDR) in 2004 in order to promote common understanding and definitions of risks affecting territories and populations.

The definition also claimed that the concept of vulnerability is thus directly connected to the physical and spatial characteristics of places such as underdevelopment, unplanned urban growth, poverty, deforestation and changing land use. These factors can influence the coping capacity of an area to face and manage adverse conditions, emergencies or disasters by using the available skills and resources (UNISDR, 2009). For example, soil sealing activities have direct repercussions on the water cycle, and they can increase the impacts of meteorological phenomena in hydrogeological risk-connected areas.

Moreover, in addition to natural hazards, the vulnerability of an area is affected by urbanization processes, which have the capacity to generate new hazard events. Such events are considered as man-made hazards that are caused by humans, and they can occur within or close proximity to human settlements. For example, these hazard events are industrial and transport accidents, environmental degradation and pollution. The latter, associated with manufacturing, food processing and construction, can lead to the release of heavy metals, plant nutrients and organic compounds to the environment and soil (Douglas, 2006). They can impose severe impact on the health of ecosystems and the human population (Allen, 2006) living in affecting territories.

In particular, these processes occur and overlay especially in peri-urban areas of the contemporary city. In relation to the issue of risks, in fact, these areas have a double connotation (Galderisi, 2017; Russo \& Attademo, 2020): on the one hand, due to its spatial characteristics of hybridization and coexistence of natural, rural and urban components (Wandl et al., 2014), these areas experience overlaps between

\footnotetext{
${ }^{1}$ Conventionally, risk is expressed by the notation Risk $=$ Hazards $\mathrm{x}$ Vulnerability. There are many aspects of vulnerability, arising from various physical, social, economic, and environmental factors. They are defined as characteristics and circumstances of a community, system or asset that make it susceptible to the damaging effects of a hazard (UNISDR, 2004, 2009).
} 
natural (e.g., floods, landslides) and anthropogenic risks (e.g., pollution due to the release of organic and inorganic waste). Thus, in peri-urban areas, high- and lowdensity residential settlements could rise near industrial areas, cultivated fields or abandoned landfills. At the same time, peri-urban areas are the places where the impact of uncontrolled urbanization and landscape fragmentation occur.

The increasing awareness that risks are closely related to anthropic activities and urbanization has highlighted the need to frame risk-related issues in a broader framework of urban development and sustainability (Galderisi, 2017). Nowadays, the issue of settlements at risk is one of the main challenges of international policies on sustainable development (e.g., the 2030 Agenda for Sustainable Development; United Nations, 2015). Goal 11 of the Sustainable Development Goals states the need for the improvement of risks mitigation and the resilience of exposed settlements. In Italy, the prevention of natural and man-made risks is also a strategic objective of the National Strategy for Sustainable Development (SNSvS) which promotes integrated and multi-sectoral policies involving the fields of "people, planet and partnerships" (Ministero dell' Ambiente, 2017). It is necessary to emphasize that the goals highlight the need to minimize polluting loads in the soil, the water and the atmosphere.

In this framework, the peri-urban regeneration represents a main challenge for regenerative urban planning, and its project can only start from the knowledge of the risk and vulnerability conditions of the affected areas. In a circular approach, however, the vulnerabilities of settled environments, such as ecological fragmentation and unplanned construction, become resources for the recomposition of the landscape. Through strategies and design actions, they can tackle the emergence of new risks.

\subsubsection{Territorial Risks and Resources in Campania}

As an example of coexistence between natural and man-made risks in vulnerable territories, this research focuses on Campania region, the third most populous region of Southern Italy with an area of $14,000 \mathrm{~km}^{2}$ and almost six million inhabitants (Eurostat, 2018).

Given its location and morphological composition, Campania region is affected by a number of natural risk factors. The region stretches between the Apennine Mountains and the Tyrrhenian Sea, and extinct and active volcanic complexes dominate its natural landscape, such as the Vesuvius, the Campi Flegrei complex and the volcanic island of Ischia. Although the natural risk factors are high in these volcanic areas, they have been populated since ancient times, making natural and anthropic risks intertwined. Over the last century, the natural risk determined by the morphological conditions of the region has been worsened by a rapid urbanization process transforming the hinterland from a rural reality to a metropolitan conurbation without a shared institutional vision (REPAiR, 2018a; Russo, 2011) between Naples and Caserta. 
The process of urbanization still seems to proceed in spite of the risk conditions of the territory in Campania. In 2019, land consumption in the region reached a record level, with $10 \%$ of total land lost in a year (corresponding to 140 hectares). More than $70 \%$ of the "lost lands" coincide with areas already exposed to natural hazards (seismic and hydrogeological) (Munafò, 2020).

Furthermore, land consumption processes take place in a very weak and obsolete planning context: only 13\% of the Campanian municipalities have approved the Municipal Urban Planning Plan (PUC), as it is defined by the current regional law (L.R. 16/2004). Some remaining municipalities (54\%) have initiated the official procedures, while others (33\%) have not initiated any steps for the approval of the PUC (Moccia, 2018). In this context, however, it should be emphasized that the regional laws do not establish the mandatory consistency between urban planning and planning tools for the emergency management (Galderisi et al., 2020).

Urbanization processes, including the development of illegal settlements and locations of production activities, have promoted the emergence of new human-made risks such as the contamination of soil and water, hazardous material spills, fires and environmental pollution. These risks contribute to the increase in the marginalization of the area, the decline of local agriculture and other human activities. The result is an extensive conurbation developed around the old towns with many urban fringes and peri-urban areas that are characterized by the coexistence of non-built fragments, discontinuous and low-density-built environments, productive and commercial settlements as well as rural fields (REPAiR, 2018) (Fig. 3.1). The remainder of the countryside is bisected by local and national level transport infrastructures that are poorly integrated with each other, and they draw a "grey arabesque" on the territory (Fatigati \& Formato, 2012a).

Such infrastructures in a rural environment have activated a process of abandonment of agricultural production sites. They have also generated agricultural areas that are waiting for transformations and have exacerbated the architectural gap between higher level infrastructures and the quality of the surrounding settlements (Amenta et al., 2018).

Due to these spatial features, such as the availability of open space and good accessibility from urban areas, the peri-urban interface has also worked as a backyard (Allen, 2006) for legal and illegal urban waste disposal sites, and for the production and disposal of polluting substances. The degradation of soils and ecological condition of the investigated territory depends not only on the residues of the industrial activities, but upon the irregularities found in the waste management cycle as well. Campania region has experienced several emergencies in its waste management cycle over the past few years. Currently, two thousand toxic substance dumping sites, along with the illegal burning of wheels, plastics, textiles and other residuals, still represent major concerns for environmental and population health ${ }^{2}$ (Mazza et al., 2015). The affected areas are included in the registers of contaminated sites drawn up by the

\footnotetext{
${ }^{2}$ In line with the notion of the peri-urban area as a "backyard", the waste crisis has been partially solved by building a waste incineration plant in the peri-urban area of the metropolitan city of Naples (Municipality of Acerra).
} 
NFH6. In the fields

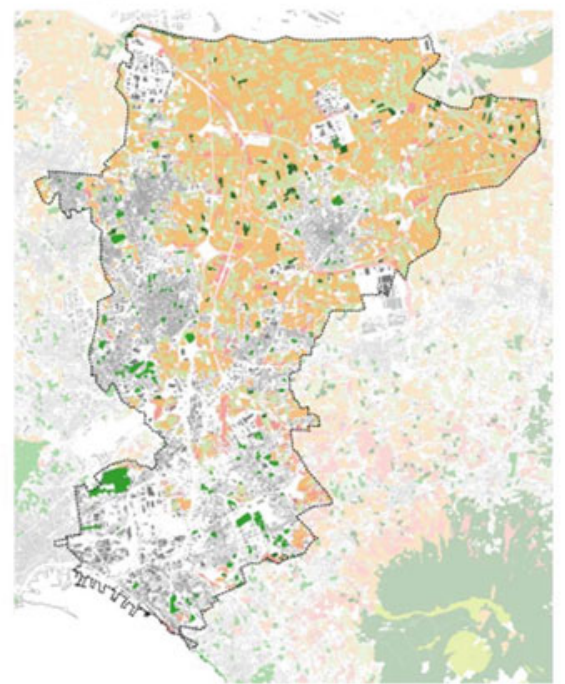

NFH7. Risk condition

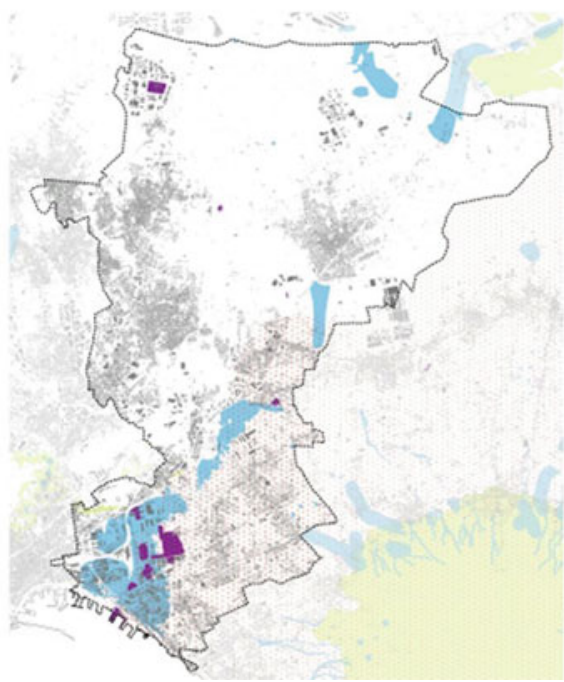

NFH4. Plot division

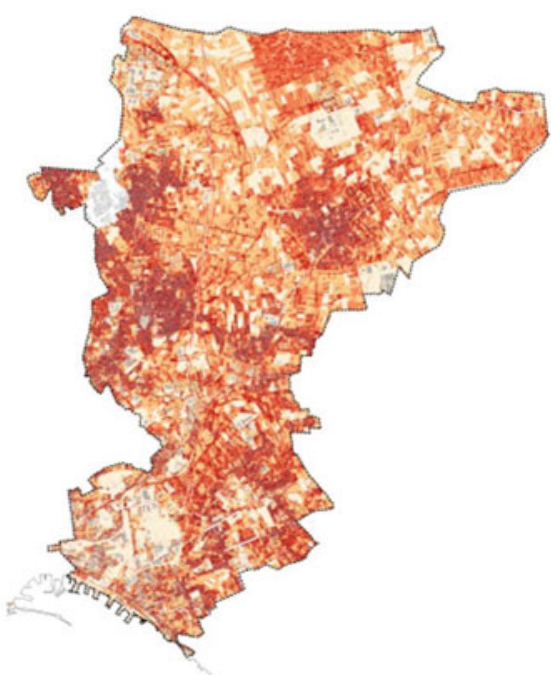

NFH3. Degraded land

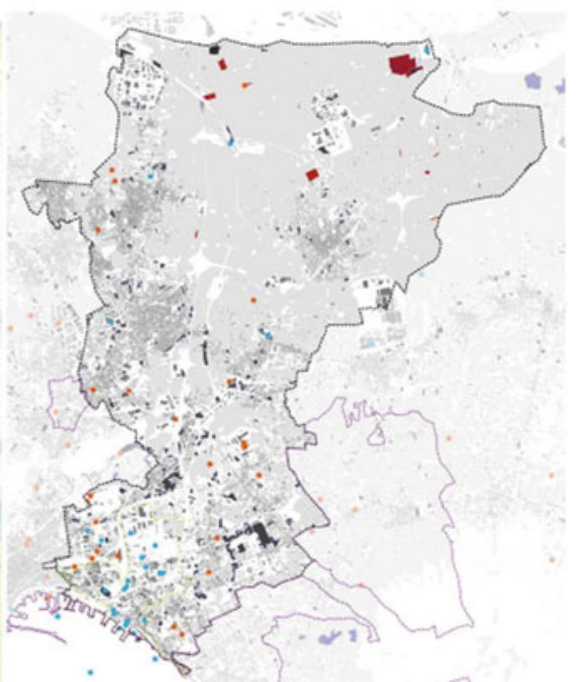

Fig. 3.1 Thematic selection of REPAiR spatial analysis on a Focus peri-urban area in Campania. NFH6: location of agricultural fields surrounding settlements and infrastructures. NFH4: vulnerability of rural areas linked to the landscape fragmentation; NFH6: areas related to natural (volcanic, hydrogeological) and industrial risk. NFH3: potentially polluted and polluted areas (Source REPAiR, 2018) 
Region of Campania (RL No. 685/2019) and the National Government (Lex No. 426/98).

The area covered by illegal dumping and burning of waste, that was previously socalled the Land of Work ("Terra di Lavoro") has become the Land of Fires ("Terra dei Fuochi"). The latter term appeared for the first time in the 2003 Legambiente Eco-mafie report ${ }^{3}$ and later, it has been used by national laws that have recognized the risk of pollution in these areas (Lex No. 6-6 February 2014). For these reasons, as established by these laws, and after surveys and analyses, cultivation for food purposes in affected crops has become prohibited. As a result, the open space, the endless horizon of the countryside has turned into residual space, which is sometimes abandoned, sometimes polluted, and is no longer productive.

Internally, the existence of risk, in anthropogenic and natural terms, triggered a state of crisis, of suspension between the end of a life cycle and the start of a subsequent one. These soils, settlements and water of the peri-urban landscape are often labelled in the literature as wasted landscapes (Amenta, 2015). The term "wastescapes" introduced later by the REPAiR project (REPAiR, 2018a) also signifies a call for urgent regeneration strategies to mitigate the risk of pollution, to repair environmental damage and to reconstruct the peri-urban landscape.

As a result, peri-urban areas have become incubators of major problems linked to a number of anthropic risks mentioned above: waste management, presence of illegal settlement, soil sealing, soil pollution, increasing the level of vulnerability of rural fringe interface.

What results interesting within this contribution, is the dualism of the risks related to this specific territory: despite the above-mentioned risks, the environmental character of the region has a number of advantages. For example, numerous thermal baths and the very fertile agricultural production in the region both have benefited from the volcanic systems and sulphurous soil. In the same way, the risk of flooding and the marshy characteristics of the Campanian hinterland have historically been sources of agricultural fertility. The reclamation works on the marshes have shaped the fertile plain of Campania since the 1500s, when it was called "Land of work" (Terra di Lavoro) for its fertility and productivity. This productivity made the region one of the largest exporters of agricultural products such as hemp or flax until the 1900s (Casoria \& Scognamiglio, 2006).

Urban agriculture is still at the top of the brown and green global agendas and in scientific research (as detailed in Sect. 3.2). However, focusing on peri-urban agriculture as opposed, for example, to urban or vertical gardens issues, means putting the environmental and landscape dimension of agricultural practices at the centre of research. In this research, peri-urban agriculture is thus investigated in terms of

\footnotetext{
${ }^{3}$ Legambiente is the most widespread non-profit environmental association in Italy. Among the main activities: "analysis and reporting of environmental crime, eco-mafia, trafficking and illegal disposal of waste, exploitation of animals and illegal building" (source: legambiente.it) through reports and scientific studies, along with active participation and volunteer campaigns.
} 
potentials of recycling of organic and inorganic flows (organic waste, wastewater) and of regeneration of wasted landscapes (wastescapes) in peri-urban areas.

For the above reasons, together with the solid rural culture and the traces of rural landscape that the Campanian peri-urban areas have preserved, the agricultural vocation of the region has been considered as a resource for the regeneration of this land at risk.

\subsection{Land Productivity: From Exploitation Toward Regeneration}

The countryside is back on the scene!

As stated in the previous section, the risk in Campania region is linked to the latent productivity of its soil.

In particular, the identification of peri-urban, as the principal site wherein shifting such compromise and risky sites into challenging places in which can take place a sustainable agricultural practice, has been a common challenge of European agendas for the past 20 years so far. Furthermore, several European and national studies have focused on plans, programmes and research projects on the sustainable productive aspect of peri-urban. ${ }^{4}$ Thus, as understood within the EU project PLUREL-Periurban Land Use Relationships, Strategies and Sustainability Assessment Tools for Urban-Rural Linkages, ${ }^{5}$ EUROPE 2020 is a potential driver of policy innovation for "territorial cohesion", using the peri-urban as a suitable place to integrate economic, environmental and social aspects (Piorr et al., 2011). Moreover, as emerges from PLUREL, urban expansion is by far the most rapid type of land-use change in Europe, and it will continue at a rate of $0.5-0.7 \%$ per year. Following these results on the growth forecast of peri-urban areas, the European Environment Agency ${ }^{6}$ (EEA)

\footnotetext{
${ }^{4}$ Among others, Urban Sprawl in Europe. The ignored Challenge, Bruxelles 2006; New Challenges for Agricultural Research: Climate Change, Food Security, Rural Development, Agricultural Knowledge Systems, Bruxelles 2008; PLUREL (Peri-urban Land Use Relationships-Strategies and Sustainability Assessment Tools for Urban-Rural Linkages). Coordinated by the University of Copenhagen (2007-2011); PAYS. MED. URBAN. Peri-urban Landscapes (2009-2012) within the European Med Programme (2007-2013), AGAPU (Analisi e Governo dell'Agricoltura Periurbana) research project n. 1724, funded by the Regional Research Programme in the agricultural field (2010-2012), Lombardia Region-Plan20; REPAiR (REsource Management in Peri-Urban Areas: Going beyond Urban Metabolism) coordinated by TU Delft (2016-2020).

${ }^{5}$ PLUREL-Peri-urban Land Use Relationships-Strategies and Sustainability Assessment Tools for Urban-Rural Linkages-is an integrated project funded by the 6th Research Framework Programme of the European Union. 32 partners from 14 European countries and China participated in the project. It has been coordinated by the University of Copenhagen. The project started in 2007 and terminated in April 2011. Available at: www.plurel.net.

${ }^{6}$ The European Environment Agency (EEA) is an agency of the European Union, whose task is to provide sound, independent information on the environment. The EEA aims to support sustainable
} 
argues that by 2020, "approximately $80 \%$ of Europeans will be living in urban areas". As a consequence, peri-urban, classified as "discontinuous areas", will grow four times faster than "continuous areas", i.e., the urban ones ${ }^{7}$ (EEA, 2017).

Based on this overwhelming change of land use, projects and proposals which use agriculture production to contrast urban expansion and to rethink the organization of cities are increasingly emerging. In addition, the economic support to agricultural enterprises will no longer be linked to the quantity of production, but a quality production and rural development policy will be rewarded. ${ }^{8}$

Therefore, examples around the worlds, such as the project by Rem Koolhaas, Countryside: The future (2020), exhibited in the Guggenheim Museum, or the project for the Lisbon Triennale by Sébastien Marot, Agriculture and architecture: taking the country's side (2019) are just a few of the many cases. Such projects contribute to bringing old concepts back into vogue, in particular the once associated with the well-being produced by the countryside and its value as a binder. Concepts that are the sons of the Kropotkin's collaborative field, of the Howard's Garden City, and even later of the Wright's Broadacre City and Branzi's Agronica. Those projects have considered social integration in various ways to rebuild the relationship between nature, culture, city and countryside.

Based on the examples above, how, even in Campania Region, can agriculture be used for the peri-urban regeneration project?

As we have mentioned earlier, the volcanic soil, together with its geographical position, has contributed to the fact that in the past, Campania was known as "Land of Work" (Terra del Lavoro) or Campania Felix. The adjective felix referred to the fertility and productivity of the region. The agricultural hinterland of Campania has always played a fundamental role for the inner city, as a productive place on which the urban economy depended.

What is left today? Is it still felix? "Campania Felix represents an emblematic case study: the waste crisis, the congestion of the coastal city, the transformation of the countryside from land of production to stand-by land (of new settlement, landfills, etc.), the pervasive informal settlements" (Fatigati \& Formato, 2012b).

The goal is to explore and analyse innovative ways of agricultural production. Such examples have been considered by the aforementioned PLUREL synthesis report. This report has pointed out that as the levels of urban growth and related agricultural land consumption continue, "land fragmentation, loss of habitats and amenity values will all be more serious in the peri-urban than today" (Piorr et al., 2011).

development by helping to achieve significant and measurable improvement in Europe's environment, through the provision of timely, targeted, relevant and reliable information to policy making agents and the public.

7 "A set of urban areas laying less than $200 \mathrm{~m}$ apart". Those urban areas are defined by the land cover classes considered to contribute to the urban tissue and function (EEA, 2017).

${ }^{8}$ Look at the webpage of the Italian Farmers Association (Cia-Confederazione Italiana Agricoltori). Available at: https://www.cia.it/documenti/lagricoltura-negli-spazi-periurbani/. 
As reported by the data of the last Italian census (Italian National Institute of Statistics-ISTAT), the expansion of dispersed built-up areas has increased pressure on peri-urban and rural areas. In peri-urban areas, change in rural land use is mainly due to land abandonment and the transition to artificial areas. Between 1982 and 2013, the utilized agricultural area (SAU "Superficie Agricola Utilizzata") decreased by $21.5 \%$. In just three years, between 2010 and 2013, more than 400,000 hectares of agricultural land were lost. A further estimate reported that between 2004 and $2009,7.3 \%$ of the national territory passed from "agricultural" to "natural" $(3.7 \%)$ or "artificial" $(0.9 \%)$, but also to a not negligible extent from natural to agricultural (1.9\%) (ISTAT, 2017).

In Campania, the decrease in the number of farms $(-41.6 \%)$ was far greater than the decrease in the Utilised Agricultural Area (UAA) $(-6.3 \%)$ and the Total Agricultural Area (SAT) (-13.8\%) between 2000 and 2010. According to this data, the thesis argued in this paper is that working in rural peri-urban areas-where the human presence is greater than in the open countryside-can have its advantages, as, right there, agriculture is strongly influenced by urban areas.

Therefore, in order to analyse sustainable agriculture and new territorial strategies, a shift is needed in the planning process (Buxton \& Butt, 2020).

Such rethinking and development depend on the definition of planning instruments, capable of considering the structural, perceptive, productive and social aspects of the agricultural landscape.

For example, the Regional Landscape Plan for the Puglia Region. In this plan, what is considered as "border condition" can drive a design of what is defined as "deal between the city and the countryside", 9 involving people in the governance process and defining a "new geography" of the territory (Donadieu, 2013; Magnaghi, 2010; Mininni, 2013a, b; PPTR Puglia, 2015).

This suggests that it is necessary to define integrated interventions of rural development and urban and land-use planning in order to harmonize the city/countryside relationship, and to make those areas more attractive from a social and productive point of view.

As stated above, the problem of agricultural areas on the outskirts of cities is perceived and addressed at European level. Then, the objective to address is a multidimensional project able to restore the ecological and productive qualities, revealing the original vocation of these fields, through a circular approach (Allen, 2003; Bogaert et al., 2015; Chen et al., 2019; EESC, 2004; Gonçalves et al., 2017; Hedblom et al., 2017; ICESP, 2019; Olsson, 2016; Piorr et al., 2011).

In doing so, local tradition and process innovation are bound together, with the aim of rethinking how these places deal with the more fragile interface: the peri-urban one. Thus, "peri-urban agricultural areas represent considerable potential as agricultural parks, green areas of metropolitan interest, where it is essential not to disregard the encouragement of non-invasive productive activities, increasing the agricultural functions of quality both on the agro-food-biological and on the aesthetic-landscapecultural level" (Regione Lombardia, 2012).

\footnotetext{
${ }^{9}$ In Italian: "Patto Città-Campagna", i.e., the main purpose of the plan and its own title.
} 
The potential character of the peri-urban concerning its association to agricultural lands already emerged in one of the first definitions of the peri-urban, i.e., Pierre Donadieu's "Campagne urbane" (Donadieu, 1999, 2013). Through this apparent oxymoron, Donadieu explains that peri-urban agriculture must be understood as a natural infrastructure of public interest that can be used for several ends: to recycle organic waste coming from the city, as horticultural space, for leisure, educational farms, community engagement, etc. Thus, the built and the unbuilt work together to transform the rural-urban fringes into an available and productive landscape (Donadieu, 1999, 2013). Then, to shift the "agricultural peri-urban space" into a "campagne urbane", it will be necessary for the population who live there to accept its allegory and transform it into a liveable place (Mininni, 2013a, b).

Nevertheless, thinking only about the potential that lies in supporting sustainable architecture cannot be separated from thinking about these places in terms of design (Hedblom et al., 2017). As Michael Button and Andrew Butt have claimed recently, peri-urban regions hold high strategic, social, economic and environmental significance, and planning for the future of these areas results in extremely challenging (Buxton \& Butt, 2020).

How to rethink these territories? How can productivity become a driver for innovation, both technological and spatial? How can its raw elements be useful for its design? And then, how to make Campania felix again?

\subsection{Adaptive Remediation Approach for Peri-Urbanity in Transition}

Acting within fragments of peri-urban territory means dealing both with their intrinsic potential, in ecological and productive terms, and with complex dynamics that distinguish the condition of "waste", exposure to risks, of human and natural matrix, and poor resilience to the pressures and vulnerabilities that derive from it.

Increasing the adaptive capacity of these places "in transition", insisting on their current metabolism, and on the inefficiency of the linear chain (productionconsumption-waste), involves their transformation from territorial value producers to promoters of resource flows (van Timmeren, 2014).

In this sense, the transition from a linear to circular chain involves re-reading and rethinking the peri-urban context in a regenerative way through its orientation towards new life cycles, new economies and productivity, contemplating more sustainable and eco-friendly farming practices.

As stated above, a sustainable approach to agriculture contributes to the longterm maintenance of productivity, social utility and environmental protection (Ikerd, 1993; United Nations, 2009) by means of integrated soil management (OECD, 2008), hindering the alteration of its biological composition and preserving its agronomic and environmental quality. 
However, the soil quality of the once agricultural rural fringes in Campania is undermined by degradation processes. The main cause of these phenomena is the use of the soil as a mere platform to support improper agricultural practices. These phenomena are also related to the disproportionate land consumption, with significant ecological compromises in terms of contamination and pollution. Therefore, it is necessary to reverse the course, and to turn these premises into pretexts to place agriculture in a more sustainable dimension and trigger regenerative, safety or remediation practices, for profitable future developments in a circular perspective.

To do that, the urban project investigates and insists on the existing condition of the places. It also promotes the reuse of the landscapes, by replacing the concept of expansion with recovery. This also implies a review of the useful devices to implement this transition. The latter, from specific and sectoral ones, are set up as tools for the prefiguration of transcalar, intersectoral and innovative design strategies (Pavia, 2014).

Among these, environmental remediation interventions play primary roles based on an adaptive and ecological spatial interpretation. They reject conventional operational solutions, and they highlight the limitations of traditional approaches. The latter, in fact, conceal synchronous matrices that are aimed at the restoration of primitive and short-sighted conditions not related to any soil design. In this case, the output materializes in fruitless spatial restitutions extraneous to its identity schedule as well as disconnected from the real and concrete needs of the established communities. However, the transition to integrated and sustainable methods of intervention aims to create a context of regenerative and adaptive development. Also, it allows to orient remediation actions in a diachronic key according to an evolutionary approach, in time and space, for the restitution of public space with ecological value (Robiglio et al., 2014).

This premise could be pursued by triggering new processes and approaches to remediation, aimed at intercepting the best solution that maximizes the benefits from environmental and socio-economic points of view (e.g., from a circular perspective, the reuse of the site in question).

In this view, the peri-urban agricultural territory is configured as an urban system that is able to resist and to react to change by reinventing and renewing itself, through the construction of timely social, economic and environmental responses, and becoming productive again but in a different way. The available space is limited and fringed, but the urban interface can be used to our advantage. It can be used as an area where mutual exchange takes place between the city and the countryside, and where innovative development plans are developed. Therefore, it is configured as a new laboratory of experimental production $\mathrm{Km} 0$. Within it, the intervention of reclamation becomes a precondition for the future development of the territory as well as a device able to outline tactical actions of change hinged on shared, ecological and innovative vision for a new peri-urban condition in which communities can recognize themselves.

A sustainable approach to reclamation is a preferred framework in which recovery and innovative solutions optimize the use of resources, and they provide long-term benefits. Among these, there are some technically defined Nature-Based Solutions 
(NBS). ${ }^{10}$ Placing themselves in a wider eco-innovative ${ }^{11}$ frame, the NBS include a series of ecosystem and site-specific approaches, and they are implemented individually or integrated with other solutions combining economic, governance and social innovation. Particularly supported at a global level, ${ }^{12}$ they contribute to improving the resilience of peri-urban areas by means of mutually beneficial ecological processes, while increasing the value of the sites, and defining new local business models. One significant step ahead has been made in promoting the ecosystem-based approach by the recent publication of the Decree 46 of 1 March 2019 (Official Gazette 132, 7 June 2019) that has dealt with the Regulation of remediation, reclamation and safety measurements of agricultural areas. Despite the Italian situation being regressive in comparison to European trends in terms of sustainable management and regulation of land reclamation, the peri-urban area is the preferential framework in which such measures are implemented. In Annex 4 of Decree, it is established that “... the protection of landscape and of agricultural vocation of an area remain one of the strategic objectives of land management and planning", and "they will be the preferred actions of bio- and phytoremediation with multiannual crops that have many advantages in comparison to physical and chemical treatments".

Such approaches, with an irrelevant economic impact, promote the effective safety of the site, prevent the non-agricultural use of the soil, improve the quality of perception of the landscape, in addition to the improved fertility of the soil.

\subsection{The Agency of Waste}

The applicability of the issues and concepts introduced was tested in the framework of the European project REPAiR, funded by the Horizon 2020 framework.

Starting from an in-depth investigation of the fragmented peri-urban areas in Campania region, the conditions for the reconstruction of a landscape were verified.

\footnotetext{
${ }^{10}$ Nature-Based Solutions are related to living solutions inspired and continuously supported by and using Nature designed to address various societal challenges in a resource efficient and adaptable manner and to provide simultaneously economic, social and environmental benefits (Walters et al., 2016).

${ }^{11}$ Eco-innovation refers to all forms of innovation-technological and non-technological-that creates business opportunities and benefits the environment by preventing or reducing their impact, or by optimising the use of resources. Eco-innovation is closely linked to the way we use our natural resources, to how we produce and consume and also to the concepts of eco-efficiency and eco-industries. It encourages a shift among manufacturing firms from "end-of-pipe" solutions to "closed-loop" approaches that minimise material and energy flows by changing products and production methods-bringing a competitive advantage across many businesses and sectors (EC, 2013).

${ }^{12}$ For further information see EU Research and Innovation policy agenda for Nature-Based Solutions and Re-Naturing Cities to network of national and regional funding organisations like BiodivERsA ERA-Net (EU, 2015).
} 
For example, the environmental rehabilitation intervention was mainly oriented to meeting the safety requirements of the places, the restoration of ecosystem biodiversity and the need for landscape reconfiguration (Vittiglio, 2020).

The operational strategy undertaken also helped to dispel false myths about the Land of Fires phenomenon. Recent studies and monitoring carried out by a European Commission project called Life ECOREMED (Ecoremed, 2015, 2017) on the health status of the soil in the Campanian Plains have shown that only 30 hectares of the 50,000 hectares of total land analysed were potentially contaminated. Nevertheless, the quality of the fruit and vegetable products grown in these potentially contaminated areas was also above the national average (Di Gennaro, 2018).

Within the project, the proposed urban regeneration strategy has combined two distinct Eco-Innovative Solutions (EIS; REPAiR, 2018): integrating the treatment of organic waste with potentially polluted soils for the definition of a new system of restoration and remodelling of land, of "new soils" as porous borders between urbanized and rural areas (Garzilli et al., 2020; Russo et al., 2019).

In the first instance, the strategy considers an EIS working mainly on the potential of a traditional approach to remediation. This approach, in addition to the safety of the place compared to the presence of potential contaminants in ecological matrices, aims to facilitate a transition from more consolidated and sectoral remediation approaches to more sustainable ones. In this sense, remediation operations are processes aimed at finding the best solution, in participatory contexts, which maximize the environmental and socio-economic benefits and are placed in a circular perspective, and therefore more sustainable, reuse of the site in question (Vittiglio, 2020).

The context of intervention is a fragmented peri-urban area circumscribed by the road infrastructure of the Median Axis and the water infrastructure of the Regi Lagni. In this area between Afragola and Acerra, empty and residual spaces are located, mainly with agricultural focuses.

In this area, there is the landfill called Scafatella that has been abandoned for over thirty years. Previously, it was used as a storage site for solid urban and construction waste. The landfill was also included among the potentially contaminated sites in the Regional Reclamation Plan. The choice of a naturalistic approach was the result of soil tests carried out directly on the surface of the landfill and on surrounding areas which have completely refuted this hypothesis, attributing the alterations of the metals intercepted in the soil, including Beryllium, Lead, Zinc and Thallium, uniquely to its geological composition (Ecoremed, 2015, 2017). Therefore, the experimentation has opted for the use of phyto-technologies aimed at the safety of places and restoration of biodiversity, also helping to meet the needs of landscape reconfiguration in an uncontaminated context.

To implement the phyto-remediation process, the EIS selects agronomic proposals typical for the place and suitable for this purpose. Hyper-accumulative species (e.g., Cannabis Sativa, Arundo Donax, Poplar) can function as a high buffer in the presence of potential pollutants. Among the proposed species, hemp, within regenerative practices of landscape, has direct benefits from an environmental point of view, but also indirect effects on the economic and social dimensions. The innovative component of the EIS is not so much product innovation as process innovation, which allows the 
strategy of action to be oriented towards circular perspectives. As for the product, the use of hemp is oriented towards reuse at the end of the life cycle of the crop.

This perspective is closely linked to what constitutes the EIS innovation in terms of process. As a result, the introduction of a short supply chain allows to combine the agronomic development of new crops with the recovery of the specific area considered. Moreover, the proposed solution aims to promote a local circular economy, potentially improving employment opportunities.

At local scale, the trigger of the short supply chain is also favoured by the second EIS. The latter is linked to the collection and treatment of organic waste, and it was developed synergistically to the previous for the realization of the first mentioned new soils (Garzilli et al., 2020; Russo et al., 2019). In this case, the innovative component lies in the hypothesis of placing medium-size treatment plants for the organic waste within "enabling contexts" mapped into peri-urban areas (REPAiR, 2018, p. 26). Such a position between the city and the countryside and the dimension of the treatment plants allow to strengthen that "deal" (PPTR Puglia, 2015) (Fig. 3.2). It can also project this territory into a condition of productive landscape design. The new soils not only define new living spaces, but also reshape the territory by defining new morphologies. Dealing with organic waste in treatment plants located in the urban-rural interface (peri-urban) are configured as drivers of new local economies (Allen, 2003). The reuse of organic waste for the production of compost $\mathrm{km} 0$ and the creation of a neighbourhood plant (visually and technologically less impacting the territory) can define a thickening of the buffer of this fragile interface.

Thus, wastescapes shift from fragile context to productive land. The treatment and recycling of the material produced on-site are configured as functional to the production of compost to be used for agricultural and productive purposes as well as soil for naturalization and environmental mitigation.

\subsection{Conclusions}

This paper has investigated a semantic subversion of latent peri-urban space by accentuating its potential value, and encouraging its transition from a risk capacitor to a vector of productivity and innovation on a large scale. By going beyond the established concept of peri-urban territory as a chaotic mosaic of dilapidated and ecologically compromised areas, our paper has proposed a reinterpretation in terms of potential and innovative resources aimed at the urban and landscape project by reactivating the underlying and intrinsic values of the peri-urban.

Particular emphasis has been placed on the mechanisms of regeneration and reclamation of places, because they have been understood as essential processes and materials of the urban project and internalized in a more circular and sustainable operational perspective. We have argued that it is necessary to return the wasted land back to citizens, and to trigger inclusive regeneration processes. In addition, 


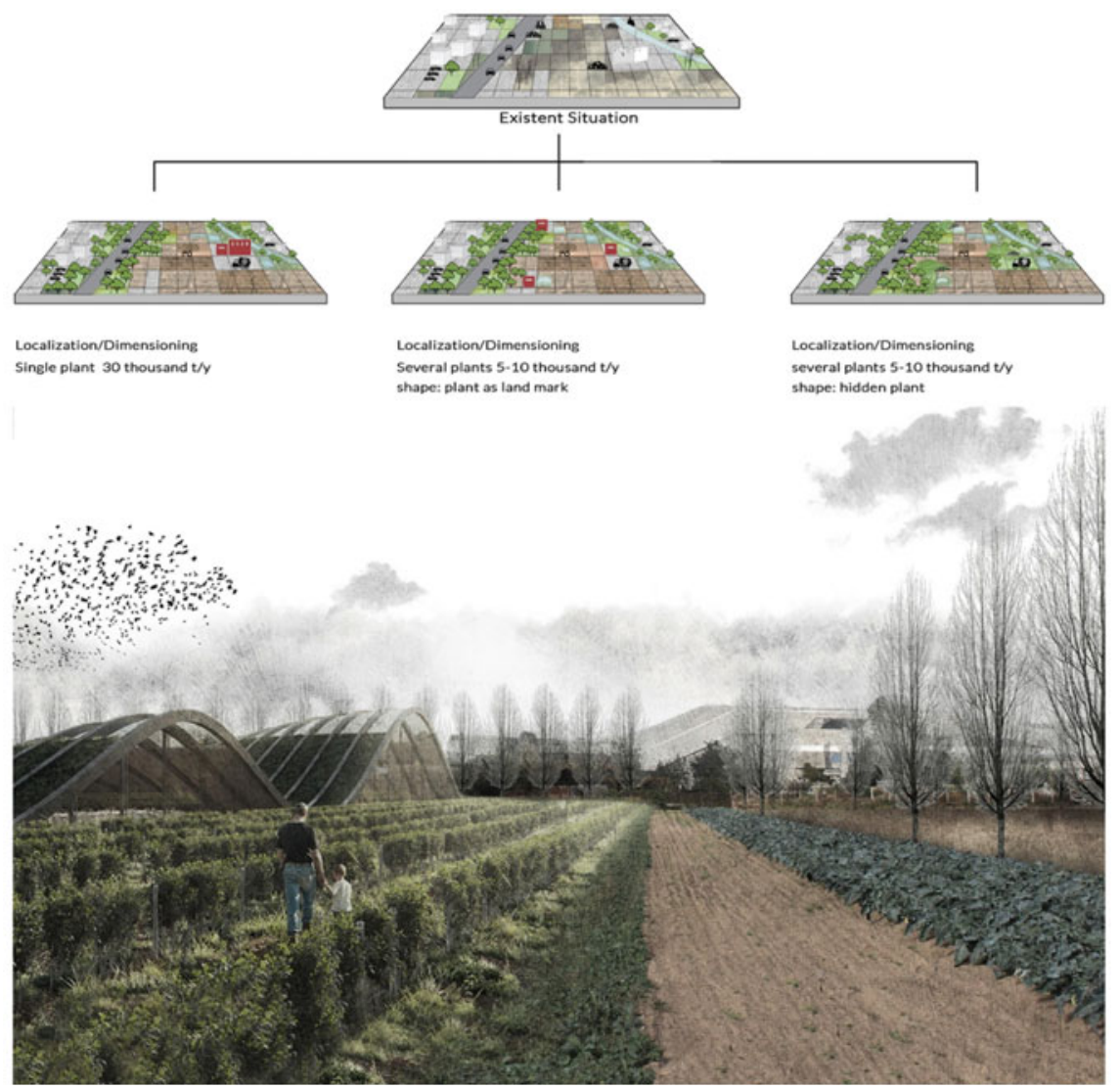

Fig. 3.2 Scenarios for the localization of the treatment plants for the organic waste. Elaborated for the Knowledge Transfer for the REPAiR PULLs. Concept and Graphic by Francesca Garzilli, 2019. Vision of hidden treatment medium-size compost plant, creation of new productive peri-urban borders. Concept image elaborated by Francesca Garzilli and Valentina Vittiglio; Graphic by Luca Esposito, 2019

unlike traditional and sectoral approaches to environmental recovery and regeneration, such operations cease to be regarded as servile fulfilment for project development. On the one hand, they mitigate the risk caused by contamination. On the other hand, they outline a new landscape, made up of common values, future visions, new opportunities and eco-based innovations.

The action in the peri-urban context becomes a driver of proactive change useful to imagine. It also defines operational lines hinged on propositive and strategic vision able to systematize the physical-spatial dimension with the environmental and socioeconomic ones. 
The technological integration of sustainable products and practices, associated with strategies and processes of territorial regeneration at a larger scale, allows these actions to be included in broader frameworks.

With targeted and integrated actions, a territorial fragility, a scrap of territory, torn and compromised, can be reactivated and stitched. The peri-urban becomes a territory of practices where to test and practices bottom-up and new local economies based on a sustainable and circular development of the territory. Such practices are considered able to face global issues such as the supply of food and energy, which weigh on urban metabolism, or the mitigation of risks related to human activities.

Therefore, this space "in transition" is configured as a preferential and priority field of action. Thus, looking at it through an ecological lens, allows us to orient towards the development of operational strategies that, focusing on sustainable regenerative solutions, lead to new life cycles, helping to increase its resilience.

Acknowledgments This project has received funding from the European Union's Horizon 2020 research and innovation programme under grant agreement No. 688920. This article reflects only the author's view. The Commission is not responsible for any use that may be made of the information it contains. Horizon 2020 European research project.

\section{References}

Allen, A. (2003). Environmental planning and management of the peri-urban interface: Perspectives on an emerging field. Environment and Urbanization, 15, 135-148.

Allen, A. (2006). Understanding environmental change in the context of rural-urban interactions. In D. McGregor \& D. Simon (Eds.), The peri-urban interface: Approaches to sustainable natural and human resource use (pp. 53-66). Routledge.

Amenta, L. (2015). Reverse land wasted landscapes as a resource to re-cycle contemporary cities. University of Naples Federico II.

Amenta, L., Attademo, A., Formato, E., \& Vingelli, F. (2018). Eco-regional perspectives. Interview with Michael Neuman in E. Formato, \& A. Attademo (Eds.), Fringe shifts. Nuove forme di pianificazione per urbanità in transizione. LISt Lab. ISBN:8898774583.

Bogaert, J., Biloso, A., Vranken, I., \& André, M. (2015, January). Peri-urban dynamics : landscape ecology perspectives. Territoires Périurbains. Développement, Enjeux et Perspectives Dans Les Pays Du Sud (pp. 59-69).

Burton, I. (2005). The social construction of natural disasters: An evolutionary perspective. In Know risk: United Nations international strategy for disaster reduction (pp. 35-36).

Buxton, M., \& Butt, A. (2020). The future of the fringe: The crisis in peri-urban planning. CSIRO Publishing.

Casoria, P., \& Scognamiglio, G. (2006). Implicazioni sociali della lavorazione della canapa tessile (Cannabis sativa L.) nel territorio di Napoli. Delpinoa, 48, 61-70.

Chen, X., de Vries, S., Assmuth, T., Dick, J., Hermans, T., Hertel, O., ... Reis, S. (2019). Research challenges for cultural ecosystem services and public health in (peri-)urban environments. Science of the Total Environment, 651, 2118-2129. https://doi.org/10.1016/j.scitotenv.2018.09.030

Di Gennaro, A. (2018). Ultime notizie dalla terra. La Terra dei fuochi: questioni per il paese intero. In Materiali. Roma.

Donadieu, P. (2013). Campagne urbane. Una nuova proposta di paesaggio della città. Donzelli. 
Douglas, I. (2006). Peri-urban ecosystems and societies: Transitional zones and contrasting values. In D. McGregor \& D. Simon (Eds.), The peri-urban interface: Approaches to sustainable natural and human resource use (pp. 41-52). Routledge.

EC. (2013). Eco-innovation. The key to Europe's future competitiveness. Directorate-General for Environment. https://doi.org/10.2779/4155. https://op.europa.eu/en/publication-detail/-/pub lication/c4769624-ea99-11e5-a2a7-01aa75ed71a1

ECOREMED, Life. (2015). Manuale operativo per il risanamento ecocompatibile dei suoli degradati. Available at: www.ecoremed.it.

ECOREMED. (2017). Operative eco-remediation protocol. Available at: http://ec.europa.eu/ environment/life/project/Projects/index.cfm?fuseaction=home.showFile\&rep=file\&fil=ECO REMED_Project-Manual_EN.pdf.

EESC. (2004). Opinion of the European economic and social committee on 'Agriculture in periurban areas.' Official Journal of the European Union.

European Commission. (2015). Towards an EU research and innovation policy agenda for nature-based solutions and re-naturing cities. Available at: https://ec.europa.eu/programmes/hor izon2020/en/news/towards-eu-research-and-innovation-policy-agenda-nature-based-solutionsrenaturing-cities.

European Environmental Agency. (2017). Urban morphological zones definition, methodological approach and results. Available at: urban morphological zones - European Environment Agency. https://www.eea.europa.eu/data-and-maps/data/urban-morphological-zones-2000-2

Eurostat. (2018). Complete profile of Campania region. Available at: https://ec.europa.eu/growth/ toolsdatabases/regional-innovation-monitor/base-profile/campania

Fatigati, L., \& Formato, E. (2012a). Facilities, Landscape, City. To the origins of a missed meeting. Travelling around the new high-speed Naples-Afragola train station. Italian Journal of Planning Practice, 2(1), 26-39.

Fatigati, L., \& Formato, E. (2012b). Campania felix. Ricerche, proposte, nuovi paesaggi 2002-2012.

Galderisi, A. (2017). Nexus approach to disaster risk reduction, climate adaptation and ecosystems' management: New paths for a sustainable and resilient urban development. In A. Colucci, M. Magoni, \& S. Menoni (Eds.), Peri-urban areas and food-energy-water nexus. Springer Tracts in Civil Engineering. Available at: https://doi.org/10.1007/978-3-319-41022-7_2.

Galderisi, A., Guida, G., \& Limongi, G. (2020). Pianificazione di emergenza e pianificazione urbanistica in Campania: un focus sull'area metropolitana di Napoli. In M. Francini, A. Palermo, M. F. Viapiana, Il piano di emergenza nell'uso e nella gestione del territorio. Franco Angeli.

Garzilli, F., Mazzarella, C., \& Vittiglio, V. (2020). Integrated approaches for peri-urban wastescapes. Eco-Innovative Strategies of the REPAiR Project in the Naples case study. International Journal of Urban Planning and Smart Cities (IJUPSC) (in proceeding).

Gonçalves, J., Gomes, M. C., Ezequiel, S., Moreira, F., \& Loupa-Ramos, I. (2017). Differentiating peri-urban areas: A transdisciplinary approach towards a typology. Land Use Policy, 63, 331-341. https://doi.org/10.1016/j.landusepol.2017.01.041

Hedblom, M., Andersson, E., \& Borgström, S. (2017). Flexible land-use and undefined governance: From threats to potentials in peri-urban landscape planning. Land Use Policy, 63, 523-527. https:// doi.org/10.1016/j.landusepol.2017.02.022

ICESP (2019). L'economia circolare nelle aree urbane e periurbane. Vol. 1. Italian Circular Economy Stakeholder Platform. https://www.icesp.it/sites/default/files/DocsGdL/Rassegna\% 20Volume\%201\%20-\%20L\%27economia\%20circolare\%20nelle\%20aree\%20urbane\%20e\% 20periurbane.pdf

Ikerd, J. (1993). Two related but distinctly different concepts: Organic farming and sustainable agriculture. Small Farm Today, 10(1), 30-31.

IPCC. (2014). Climate change 2014: Synthesis report. Contribution of Working Groups I, II and III to the Fifth Assessment Report of the Intergovernmental Panel on Climate Change [Core Writing Team, R.K. Pachauri and L.A. Meyer (eds.)]. IPCC: Geneva, Switzerland, p. 151. https://www. ipcc.ch/report/ar5/syr/ 
ISTAT (2017). Forme, livelli e dinamiche dell'urbanizzazione in italia. ISBN 978-88-458-1916-2. https://www.istat.it/it/files/2017/05/Urbanizzazione.pdf

Koolhaas, R., \& AMO. (2020). Countryside: The future. Guggenheim Museum exhibition. New York. Available at: https://www.guggenheim.org/exhibition/countryside.

Legambiente. (2003). Eco—Mafia report. Available at: www.legambiente.it.

Magnaghi, A. (2010). Il progetto locale. Verso la coscienza di luogo. Bollati Boringhieri.

Marot, S. (2019). Agriculture and architecture: Taking the country's side. Lisbon Triennale. Available at: https://2019.trienaldelisboa.com/en/exposicoes/agriculture-and-architecture-taking-thecountrys-side/.

Mazza, A., Piscitelli, P., Neglia, C., Rosa, G. D., \& Iannuzzi, L. (2015). Illegal dumping of toxic waste and its effect on human health in Campania, Italy. International Journal of Environmental Research and Public Health, 12(6), 6818-6831.

Mininni, M. (2013a). Abitare il territorio e costruire paesaggi. Prefazione. In Campagne Urbane. Una nuova proposta di paesaggio della città (pp. XIII-LV). Donzelli editore.

Mininni, V. (2013b). Approssimazioni alla città. Urbano, Rurale, Ecologia. Donzelli Editore.

Ministero dell'Ambiente. (2017). Strategia Nazionale per lo Sviluppo Sostenibile. Available at: https://www.minambiente.it/sites/default/files/archivio_immagini/Galletti/Comunicati/ snsvs_ottobre2017.pdf.

Moccia, F. D. (2018). Avanzando nel rinnovamento dell'urbanistica. Il cambiamento delle città e dei territori in contesti problematici. In F. D. Moccia (a cura di), Lo stato della pianificazione in Campania (pp. 23-47). FrancoAngeli.

Munafò, M. (ed.). (2020). Consumo di suolo, dinamiche territoriali e servizi ecosistemici. Edizione 2020. Report SNPA 15/20. Available at: https://www.snpambiente.it/wp-content/uploads/2020/ 07/Rapporto_consumo_di_suolo_2020.pdf.

November, V. (2004). Being close to risk. From proximity to connexity. International Journal of Sustainable Development, 7(3), 273-286.

OECD. (2008). OECD contribution to the United Nations Commission on Sustainable Development, towards sustainable agriculture. https://www.oecd.org/greengrowth/40476046.pdf.

Olsson, E. G. A., Kerselaers, E., Søderkvist Kristensen, L., Primdahl, J., Rogge, E., \& Wästfelt, A. (2016). Periurban food production and its relation to urban resilience. Sustainability, 8(12), 1340.

Pavia, R. (2014). No waste: progetto e rifiuti in PPC Piano - Progetto-Rifiuti (pp. 27-28). Trento. Peduzzi, P. (2019). The disaster risk, global change, and sustainability nexus. Sustainability, 11(4), 957.

Piorr, A., Ravetz, J., \& Tosics, I. (2011). Peri-urbanisation in Europe: Towards European policies to sustain urban rural futures. A synthesis report. Frederiksberg.

PPTR Puglia, R. (2015). Linee guida per il patto città campagna. Riqualificazione delle periferie e delle areeagricole periurbane.

Regione Lombardia. (2012). PAYS MED URBAN. Periurban landscapes: Landscape planning guidelines.

REPAiR. (2018a). Process model for the two pilot cases: Amsterdam, the Netherlands and Naples, Italy. REPAiR Deliverable 3.3. EU Commission Participant portal. Brussels. Grant Agreement No 688920. Available at: http://h2020repair.eu/wp-content/uploads/2019/11/Deliverable-3.3-Pro cess-model-for-the-two-pilot-cases-Amsterdam-the-Netherlands-and-Naples-Italy-final.pdf.

REPAiR. (2018b). D5.3 eco-innovative solutions Naples. EU Commission Participant Portal. Brussels. Grant Agreement No. 688920. Available at: http://h2020repair.eu/wp-content/uploads/2019/ 10/Deliverable-5.3-Eco-Innovative-Solutions-Naples.pdf.

Robiglio, M., Artigiani, E., Manzone, L., \& Davit, J. P. (2014). Adaptive reuse. Bonifiche e rigenerazione urbana. Nuove strategie per un mercato in evoluzione. Available at: https://iris.polito. it/retrieve/handle/11583/2625748/77338/Abstract\%20di\%20Adaptive\%20Reuse.pdf.

Russo, M. (2011). Città-Mosaico. Il progetto contemporaneo oltre la settorialità. Clean.

Russo, M., Amenta, L., Attademo, A., Cerreta, M., Garzilli, F., Mazzarella, C., Rigillo, M., \& Vittiglio, V. (2019). Short supply chain of waste flows for landscape regeneration in Periurban 
areas (on proceeding). In Atti del 17th International Waste Management and Landfill Symposium Sardinia 2019. Cagliari, 30 Settembre-4 Ottobre.

Russo, M., \& Attademo, A. (2020). Il metabolismo del rischio. In A. Galderisi, M. Di Venosa, G. Fera, \& S. Menoni (Eds.), Geografie del Rischio. Nuovi paradigmi per il governo del territorio, Donzelli, Roma.

van Timmeren, A. (2014). The concept of the urban metabolism (UM). Available at: https://ocw.tud elft.nl/wp-content/uploads/UrbanMetabolism_VanTimmeren.pdf.

UNISDR. (2009). UNISDR terminology on disaster risk reduction 2009. United Nations International Strategy for Disaster Reduction.

UNISDR. (2004).Living with Risk: A global review of disaster reduction initiatives. United Nations Office for Disaster Risk Reduction. Vol. II-Annexes. Geneva: UNISDR.

United Nations. (2009). The contribution of sustainable agriculture and land management to sustainable development. In Sustainable Development Innovation Brief (7).

United Nations. (2015). Sustainable Development Goals. http://www.un.org/sustainabledevelop ment/sustainable-development-goals/. Accessed 10 Aug 2017.

Vittiglio, V. (2020). Recycling wasted landscapes: Circular perspectives and innovative approaches on landscape remediation. Napoli.

Walters, G., Janzen, C., \& Maginnis, S. (2016). Nature-based solutions to address global societal challenges. Available at: http://dx.doi.org/10.2305/IUCN.CH.2016.13.en.

Wandl, D. I. A., Nadina V., Zonneveldb W., \& Rooij R. (2014). Beyond urban-rural classifications: Characterising and mapping territories-in-between across Europe. Landscape and Urban Planning 130, 50-63.

White, G. F. (1974). Natural hazards, local, national, global. Oxford University Press.

Open Access This chapter is licensed under the terms of the Creative Commons Attribution 4.0 International License (http://creativecommons.org/licenses/by/4.0/), which permits use, sharing, adaptation, distribution and reproduction in any medium or format, as long as you give appropriate credit to the original author(s) and the source, provide a link to the Creative Commons license and indicate if changes were made.

The images or other third party material in this chapter are included in the chapter's Creative Commons license, unless indicated otherwise in a credit line to the material. If material is not included in the chapter's Creative Commons license and your intended use is not permitted by statutory regulation or exceeds the permitted use, you will need to obtain permission directly from the copyright holder.

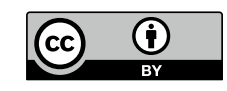

